Hydroécol. Appl. (1993) Tome 5 Vol 1, pp. 77-96

\title{
Plant management as an integrated part of Ireland's aquatic resources
}

\author{
Gestion des herbiers en tant qu'élément des ressources \\ aquatiques d'Irlande
}

\author{
Joseph M. Caffrey*
}

- Central Fisheries Board, Mobhi Boreen Glasnevin, Dublin 9. Ireland.

\begin{abstract}
Aquatic plants are fundamental to the structure and functioning of many freshwater habitats. In undisturbed aquatic habitats plants serve a multitude of important functions including the provision of substrates for colonisation by periphyton and macroinvertebrates, a direct and indirect food source for macro-invertebrates, fish and wildfowl, spawning substrates for coarse fish species, shelter for young and adult fish oxygen as a by-product of photosynthesis. In disturbed habitats, however, the natural balance among aquatic plants is altered and an excessive, often monospecific, vegetation commonly develops. This can adversely affect the beneficial use of the watercourse by diminishing its amenity and recreational potential, exacerbating water supply and flooding problems and resulting in excessive siltation in river or canal habitats.

This paper outlines the nature and extent of the more important weed problems in Irish aquatic situations and describes a range of control strategies that may be adopted to rehabilitate these habitats and to enable their exploitation by a diversity of user groups. In certain instances paucity of aquatic vegetation presents problems, including bankside destabilisation and inchannel siltation. Reed transplantation trials have been conducted in denuded Irish canals in an effort to rehabilitate these habitats and the results from these are presented.

Weed control procedures generally embrace four broad categories. These are mechanical, chemical, environmental and biological control. Of these only biological control is not widely adopted in Ireland. The effects that these procedures have on specific weeds were quantitatively investigated at a number of aquatic situations throughout the country. Results from experiments among a diversity of aquatic plant species and involving the use of mechanical weed cutting apparatus show that, unless the plant is cut to a depth at which light penetration is significantly diminished, rapid regrowth will occur and higher standing crops than might othenwise be expected may be recorded. Experimentation with a small number of herbicides has revealed that, when used with discrimination, these provide effective weed control, with little or no detrimental effect to the aquatic ecosystem. Results from trials with dichlobenil and glyphosate on aquatic and riparian species are presented. The effect that shading has on macrophyte biomass and the effect that rotted barley straw has on algal growths in watercourses is also described.
\end{abstract}

Key words. - Aquatic plants, management, rehabilitation, weed control, herbicides. 
Résumé. - Les plantes aquatiques sont des éléments fondamentaux pour la structure et le fonctionnement de beaucoup d'habitats d'eau douce. Dans les habitats aquatiques non perturbés, les plantes ont de nombreuses et importantes fonctions, incluant la fourniture:

- de substrats pour l'implantation du périphyton et macroinvertébrés,

- d'une source directe et indirecte de nourriture pour les macroinvertébrés, les poissons, les oiseaux aquatiques,

- de frayères pour certaines espèces de poissons,

- d'abri pour les alevins et les poissons adultes,

- d'oxygène en tant que sous-produit de la photosynthèse.

Dans les habitats perturbés, pourtant, l'équilibre naturel entre les plantes aquatiques est altéré et il se développe communément de façon trop abondante, une végétation aquatique monospécifique. Ce phénomene peut affecter l'utilisation du cours d'eau pour les loisirs et la fourniture d'eau potable; il peut ainsi entrainer des problèmes d'écoulement et favoriser la sédimentation.

Cette note met en évidence la nature et l'ampleur des problèmes d'herbiers aquatiques les plus importants d'Irlande et décrit une série de techniques de contrôle qui peuvent être adoptées pour réhabiliter les habitats concernés et permettre un usage à buts multiples.

Dans certains exemples, la pauvreté en végétation aquatique présente des problèmes, incluant la déstabilisation des rives et une sédimentation du chenal. Des essais de transplantation de roseaux ont été menés dans des canaux irlandais dénudés afin de réhabiliter ces habitats; les résultats sont présentés ici.

Le mode de contrôle des herbiers se présente généralement de quatre façons: mécanique, chimique, environnementale et biologique. En Irlande, seul le contrôle biologique n'est pas largement en vigueur. Les effets de ces modes de contrôles ont été quantitativement évalués dans divers types de situations réparties dans tout le pays.

Les résultats de ces expériences sur une grande variété d'espèces de plantes aquatiques et à l'aide d'une faucheuse montrent que si la plante n'est pas coupée à une profondeur correspondant à une luminosité très faible, la repousse est rapide et atteint une hauteur plus importante que celle à laquelle on aurait pu s'attendre. Les expériences avec un petit nombre d'herbicides ont révélé que lorsque cette technique est utilisée avec discernement, le contrôle de la végétation est effectif, avec peu ou pas d'effets néfastes pour l'écosystème aquatique; les résultats des essais avec le dichlobenil et le glyphosate, sur les especes rivulaires sont présentés ici. L'effet de l'ombre sur la biomasse des macrophytes et l'impact de la paille d'orge pourrie sur la croissance algale dans les cours d'eau est également décrit.

Mots-clés. - Plantes aquatiques, aménagement, contrôle de la végétation, herbicides.

\section{INTRODUCTION}

In recent years there has been increased demand for clean, wellmanagement waterways to service a wide range of domestic, agricultural, commercial and recreational activities. This trend is likely to continue as commercial and industrial water users demand water of better quality and as the use of waterways for recreational pursuit increases. 
One of the principal problems facing those charged with responsibility for the maintenance of clean and functional watercourses is that of obstructive or unsighlty aquatic plant growth. In natural, undisturbed aquatic habitats plant species intergrade and integrate, producing complex and well-balanced communities. These plants and communities hold a central position in the network of ecological relations between nutrients, plankton, macroinvertebrates, fish and avifauna (de Nie 1987). The many functions of aquatic plants in aquatic systems are described in Marshall and Westlake (1978) and Caffrey (1991a). Where this natural balance is disturbed, however, conditions favouring the establishment and proliferation of invasive plant taxa commonly results. Among the anthropogenous factors that are most often implicated in the explosive development of aquatic plants are pollution, cultural eutrophication, abstraction, impoundment and drainage. In this condition the aquatic vegetation no longer complements the functionality of the watercourse but now serves to depress biotic diversity and seriously detract from the aesthetics and usefulness of the system. As such, the aquatic plants have now become "weeds" (Navas 1991).

The aim of this paper is to describe the functional problems that weed species can illicit in a variety of aquatic habitats and to show how many of these problems may be ameliorated. The success achieved in revegetating and stabilising denuded canal banks using transplanted reed species is also described.

\section{PRINCIPAL WEED-RELATED PROBLEMS IN IRISH AQUATIC HABITATS}

Serious weed problems were not a feature of Irish watercourses prior to the 1970's (Caffrey 1991a, in press). Since that time the effects of Man's interference with water and watercourses has altered the finely-tuned equilibrium that existed among plant communities and created conditions that favour the spread of aggressive species or groups. These have, in turn, impacted upon Man's desired use of the affected waterways. In some circumstances this interference has resulted in the loss or elimination of plants, with consequent adverse impacts on species diversity, fisheries enhancement and bankside stabilisation.

In Irish rivers the most serious instream problems are presented by Scirpus lacustris (Common Clubrush), Potamogeton pectinatus (Fennel Pondweed), broad-leaved Potamogeton spp. (Pondweeds) and filamentous algae. The enrichment of many of our lotic systems from agricultural and municipal sources has made conditions for the proliferation of pollutiontolerant species, such as $P$. pectinatus and filamentous algae, more favourable (Newbold and Palmer 1979; Caffrey 1985, 1986a). The ef- 
fects of arterial drainage on many river catchments have served to create trapezoidal channels with altered flow, depth and substrate characteristics. These physical features are known to have a primary influence in the distribution and growth of macrophytes in rivers (Caffrey 1990b). This, in combination with increased sediment and water nutrient availability, creates conditions suitable for the spread of submerged and emergent Scirpus lacustris and of broad-level Potamogeton spp..

The proliferation of these species and groups and the consequent restrictions of water flow, increased inchannel siltation, flood incidents and hazards, reductions in biotic diversity, fouling of treatment plants, and other effects, have been a cause for serious concern among water and drainage engineers and others responsible for the management of watercourses. The fact that the problems are increasing in Irish watercourses highlights the urgent requirements for judicious control practices.

In some rivers, notably those slowflowing watercourses that receive drainage water from bogs under development for milled peat production, siltation has the effect of attenuating light and eliminating the submerged flora (Caffrey 1986b). This effect is reversible, however, and a submerged flora will recolonise within two to three years of the resolution of the siltation problem.

In recent years, the unprecedented spread of Heracleum mantegazzianum, a riparian plant species, has caused widespread concern among water managers, amenity groups and conservationists. The reasons for the rise to prominence of this plant in the past decade, cognisant of the fact that it has been in the country for many years, is unknown. This plant represents a serious human health hazard, impedes access to rivers, overgrows and shades-out indigenous herbaceous plants and can cause serious bankside erosion problems (Caffrey in press).

In Irish lakes and ponds, planktonic and filamentous algae present serious problems, by posing threats to recreation, water treatment and supply and, indirectly, to a wide range of lentic biotic communities. In small lakes and ponds ( $<10$ hectares $)$ problems posed by the encroachment of reed fringes or the occupation of the water surface by free-floating Lemna spp. or floating-leaved lilies (normally Nuphar lutea) are commonplace. The loss of tourist revenue to local communities as a consequence of these weed growths is often considerable and highlights the necessity for urgent rehabilitation.

Ireland supports an extensive network of man-made canals, used for navigation, angling, cancing, swimming, nature study and other waterbased pursuits. The fact that the canals are shallow, slow-flowing, possess clear and nutrient-rich water and a deep, muddy substrate means that practically all the conditions required for optimum plant growth are fulfilled (Caffrey 1991b). Weed management practices operated in the 
past concentrated on the use of one herbicide, with the result that susceptible plant species were eliminated for most of the growing season, while tolerant species were permitted to establish and spread (Caffrey and Monahan 1991). This seriously impacted the recreational fishery (Caffrey in press) and other amenity pursuits along the canals. More informed weed management practices operated in recent years have redressed some of the problems and a special research focus is being directed at outstanding weed problems.

\section{WEED MANAGEMENT STRATEGIES}

Where the beneficial use of a watercourse is interfered with, whether through the presence of excess vegetation or the total lack of an aquatic flora, some form of habitat rehabilitation will be required. This may be achieved, in cases where vegetation overgrows the watercourse, through the judicious employment of methods embraced within the following broad categories: mechanical, chemical, biological or environmental control.

Decisions relating to the appropriateness of these methods in any one instance depend on a variety of factors. These include the nature and extent of the weed problem, the use to which the water or watercourse is to be put, accessibility for cutting or spraying equipment, funds available for the project, the desirability of total or partial weed removal, among others. Thus, in watercourses used more or less exclusively for the supply of potable water, any method except chemical control should be acceptable. On the other hand, where a channel is used principally for the speedy transportation of water from land to sea, and is little used for other purposes, the use of approved, broadspectrum herbicides might be most appropriate. In most situations, however, the use of a sensible combination of all control methods available provides the most satisfactory and cost-effective solution to invasive weed problems (Caffrey in press). This integrated control procedure is widely adopted internationally (Murphy et al., 1987; Willis 1990; De Steno 1992; Caffrey in prep.) and has met with considerable long-term success.

A more detailed account of the individual methods and procedures that constitute the four broad weed control categories, and the relative merits and demerits of each, may be found in Seagrave (1988), Barrett et al. (1990), Schmidt (1990) and Caffrey (1991a, in press). The results from trials conducted on problem plant species under Irish conditions, using selected weed control procedures, will be presented in Section 5.

In aquatic habitats where a paucity of inchannel or aquatic/riparian vegetation presents difficulties for faunal and floral communities, in addition to exposing the banksides or shorelines to destabilising and 
erosional effects, urgent remedial measures are required. It is rarely sufficient to await natural plant recolonisation and the planting of seeds along the eroding margins merely represents a waste of time and money. The transplantation of living indigenous plants, preferably species with spreading rhizomes and a capacity to rapidly consolidate soil, presents a satisfactory solution. Results from such a transplanting experiment are summarised in Section 4.

\section{PRACTICAL WEED MANAGEMENT IN IRELAND - CASE STUDIES}

In this section the problems for engineers, water managers, waterbased recreational enthusiasts and conservationists that result from the over- or under-representation of aquatic and riparian plants are described. The methods selected for remedying the problems are set-out and the quantitative results from trials are presented.

\subsection{Control of Emergent Monocotyledonous Weeds}

The principal nuisance plant species in this category in Ireland are Scirpus lacustris, Phragmites australis and Glyceria maxima, although the former species is by far the most troublesome. Scirpus lacustris is heterophyllous and, depending on the flow regime in the channel, may adopt an emergent or floating-leaved habit (Caffrey 1990b). The adoption of the latter form enables the plant to colonise, establish viable populations and alter the hydraulic regime in moderate to fast-flowing rivers. Having established appreciable floating- leaved stands, the consequent reduction of flow velocities within and immediately downstream of the plant stand encourages suspended solids deposition. The reduced flow and the formation of silt/sand shoals permits the establishment of semi-emergent forms of S. lacustris, which further accelerate sedimentation. Dense and spreading stands of emergent $S$. lacustris may now occupy the full channel width and seriously impede any beneficial use of the watercourse. In fact, the presence of these obstructive vegetation stands represent a significant flood hasard in any affected watercourse.

Long sections of the River Boyne, and other Irish rivers, are totally overgrown with $S$. lacustris. Attempts by Office of Public Works (O.P.W.) engineers to control this vegetation using weed-cutting boats met with little success, for two reasons. Firstly, the vegetation was so dense that weed cutting boats were unable to make progress within the weeded channel and, secondly, the cut plants regrew rapidly and often presented inchannel problems within the same growing season.

In August 1991, at the request of O.P.W., an experimental plot measuring circa $20 \mathrm{~m}$, and including the full channel width $(30 \mathrm{~m})$, was treated 
with glyphosate at the rate of $51 \mathrm{ha}^{-1}$. Glyphosate is a broad-spectrum, foliar herbicide which is cleared for use in or near watercourses by the Ministry of Agriculture, Fisheries and Food (MAFF) in the U.K. The chemical has a very low toxicity (Bronstad and Friestad 1985, Goldsborough and Beck 1989) and is rated as practically non-toxic, the lowest classification available, by the World Health Organisation.

At the time of treatment 284 shoots per square metre occupied the channel. The following summer the treated plot was practically clear of $S$. lacustris (table 1), except for three small stands that had been missed during the spraying operation. Work conducted at the Aquatic Weed Research Unit in the U.K. (P. Barrett pers. comm.) and at canal sites in Ireland (Caffrey and Monahan 1991) suggests that three or even four years effective reed control may be achieved with one application of glyphosate.

Large-scale treatment of $S$. lacustris-infested rivers with glyphosate should re-open these channels for recreational and flood relief purposes.

Table 1. - Mean number of Scirpus lacustris (Common Club-rush) shoots per square meter in sections of the River Boyne at time of treatment with glyphosate (1991) and one year post-treatment (1992).

\begin{tabular}{c|c|c|} 
Year & No. Shoots & \pm S.E. \\
& $\mathrm{m}^{-2}$ & \\
\hline 1991 & 284 & \pm 31.4 \\
1992 & 4 & \pm 8.2 \\
\hline
\end{tabular}

Further control, when necessary, may be applied using mechanical or environmental methods. The adoption of these integrated control strategies should minimise problems with $S$. lacustris in rivers for the foreseeable future.

\subsection{Reed Transplantation Trials}

Following a major breach on a section of navigable canal in 1989, the affected channel was reconstructed and re-opened for navigation in March, 1990. By 1991, through the action of wave-wash, the clay used to line the canal bed and banksides had begun to erode. In order to expedite the natural bankside stabilisation process, it was decided to "seed" the exposed banks with roots and rhizomes from established emergent monocotyledonous plant colonies. The species selected for this purpose were Glyceria maxima, Scirpus lacustris and Phragmites australis. All three species have intricate and consolidating root and rhizome structures and are indigenous to the Irish canal habitat.

Transplanting operations were conducted in october, 1991, and a total of $5 \mathrm{~km}$ of channel was revegetated. Before the operation began planting bays along the channel, roughly at water level, were prepared. These measured circa $3 \mathrm{~m}$ in length and were separated from each other by $1 \mathrm{~m}$. When site preparations had been completed clumps of root and rhizome were planted and firmed-in with topsoil. Each species was allocated alternate $100-\mathrm{m}$ long sections. 
In September, 1992, the percentage survival among the transplanted species was assessed. The survival among $G$. maxima and $S$. lacustris plants was high (table 2) and most plants had flowered and set seed. More importantly, from a bankside stabilisation viewpoint, most of the individual plant clumps had extended their lateral range and some had coalesced with adjacent clumps. The root masses were well developed and no evidence of soil erosion in the vicinity of the plant stands was observed.

The percentage survival with Phragmites australis was significantly less (table 2) and, even where the transplanted clumps survived, only few individual shoots were recorded. There was no lateral expansion within the planted area and none of the plants flowered. The reason for the poor survival is unknown but may relate to the position, relative to water level, at which the transplanted roots were buried. Further experimentation with Phragmites will continue in the autumn of 1992 and 1993.

\subsection{Mechanical Cutting}

Long sections of weeded canal and river in Ireland are annually cut using boat-mounted apparatus. Experience with this control procedure has demonstrated that regrowth among cut plants is often rapid and may exceed that of uncut plants growing in the same channel (Caffrey 1990 a,b, 1991a, in press). In many situations it is necessary to apply two cut in the same growing season if unobstructed navigation or water movement is to be maintained. This rapid rate of vegetation regrowth normally occurs where a shallow cut is executed. During these operations the canopy vegetation, to a depth of between 0.5 and $1 \mathrm{~m}$, is cut. This removes the immediate obstruction but permits light penetration to the sections of stem, commonly between 0.5 and $0.75 \mathrm{~m}$ tall, that remain in the water column following the cut. The stimulatory effect of the cut, in addition to the increased availability of photosynthetically active radiation, results in rapid vegetation regrowth (figure 1).

Where a deep cut is applied, close to the substratum and leaving only short $(10$ to $20 \mathrm{~cm})$ lengths of stem in the water column, vegetation regrowth is generally less rapide and obstructive stands rarely develop within the same growing season (figure 1). This probably reflects the low level of light penetration to the depth at which the cut was applied. The fact that only one cut per season is required reduces the level of disturbance to the habitat and its biotic communities while also significantly reducing labour costs.

Table 2. - Percentage survival of emergent monocotyledonous plant species transplanted along denuded sections of the Grand Canal between September, 1991 and 1992.

\begin{tabular}{lrr}
\multicolumn{1}{c}{ Plant Species } & $\begin{array}{c}\% \text { Survival। } \\
\text { in } 1992\end{array}$ \\
& . & \\
Glyceria maxima & 89.28 & $=16.1$ \\
Scirpus lacustris & 81.15 & -11.1 \\
Phragmites australis : & 12.82 & \pm 4.8
\end{tabular}




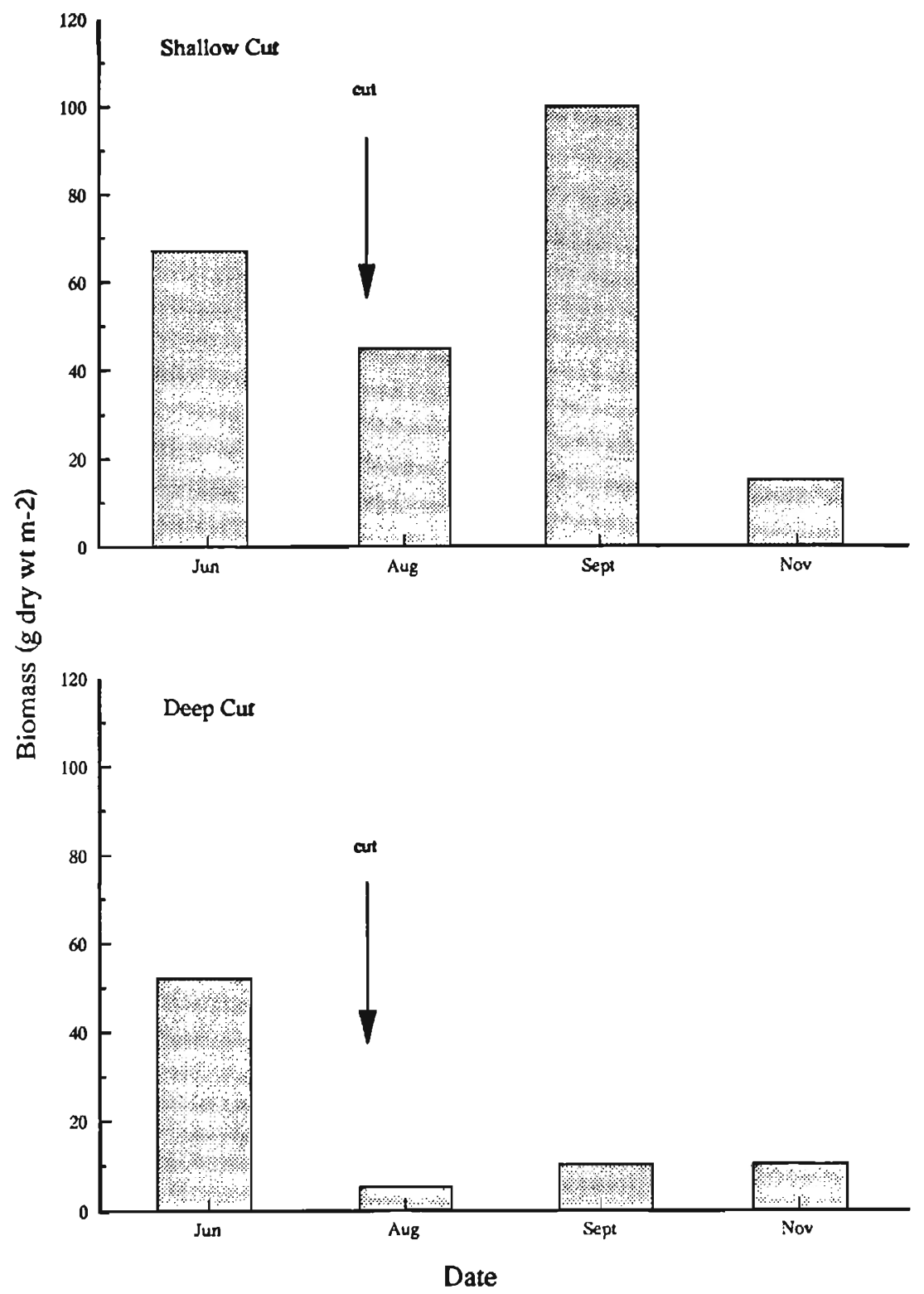

Figure 1. - The effect of shallow and deep mechanical cutting operations on the biomass of submerged vegetation in sections of the Grand Canal in 1991. 


\subsection{Shading}

Bankside shading is the most commonly adopted environmental technique used for the control of submerged plants in river habitats (Dawson and Kern-Hansen 1979; Jorga et al., 1982; Madsen and Adams 1989; Barrett et al., 1990). The success of this control procedure is based on the fact that shading by tall banks or overhanging trees can reduce the level of incident irradiance by 35 to $95 \%$, depending on the height of the banks or the aspect and leaf development of the trees (Owens and Edwards 1961). Under dense tree cover, summer irradiance may be reduced by $95 \%$ (Westlake 1975) and few submerged plants are able to establish.

The effect that dense bankside shading along sections of the Royal Canal has on the growth of Myriophyllum spp., the most prolific and troublesome species in this system, is presented in figure 2 . In shaded sections of canal practically no vegetation was recorded throughout 1992. In an adjacent unshaded section, however, dense and obstructive stands of Myriophyllum spp. were present for most of the growing season. While this result is favourable from a strictly weed management viewpoint, the virtual elimination of aquatic plants from amenity watercourses is not recommended and can have serious adverse impacts on associated faunal communities (Caffrey in press). For this reason, partial rather than total shade is preferred.

\subsection{Control of Potamogeton pectinatus (Fennel Pondweed) in Irish Rivers}

Potamogeton pectinatus (Fennel Pondweed) is a submerged macrophyte that grows luxuriantly in organically enriched habitats (Haslam 1978; Caffrey 1985, 1986) and is rapidly spreading through many of Ireland's main river systems (Caffrey 1990a, b). Once established at a site, $P$. pectinatus grows vigorously and rapidly produces dense vegetation stands. This aggressive coloniser competitively excludes most other plant species and soon establishes a virtual monoculture. Because the plant in Irish rivers is perennial and maintains a significant vegetation presence over the winter period, little opportunity for recolonisation by indigineous plant species is afforded. The presence of dense and obstructive stands of $P$. pectinatus impairs the beneficial use of infested watercourses and can result in serious ecological, hydrological and amenity resource problems (Caffrey 1991a).

Figure 3 shows the normal growth pattern for $P$. pectinatus in the lower River Shannon. Cognisant of the fact that a plant biomass exceeding $300 \mathrm{~g}$ dry weight $\mathrm{m}^{-2}$ will impair the full beneficial use of a watercourse (Westlake 1981; Kern-Hansen and Holm 1982), it is clear that serious vegetation problems are experienced in this watercourse over most of the growing season. Treatment of designated sites with dichlobenil in early-May evoked no response among the treated plants 


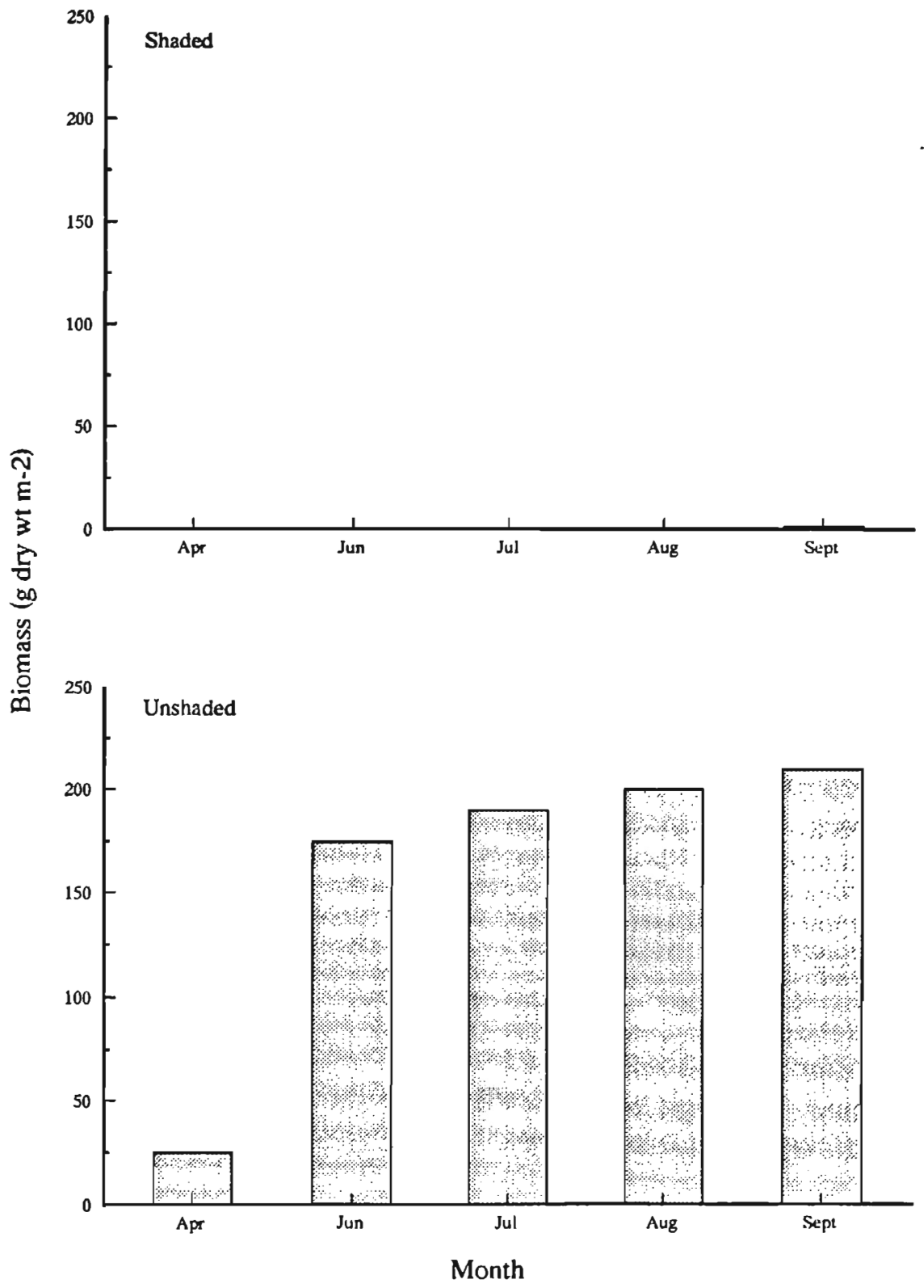

Figure 2. - Effect of bankside shading on the growth of Myriophyllum spp. (Milfoil) on the Royal Canal in 1992. 

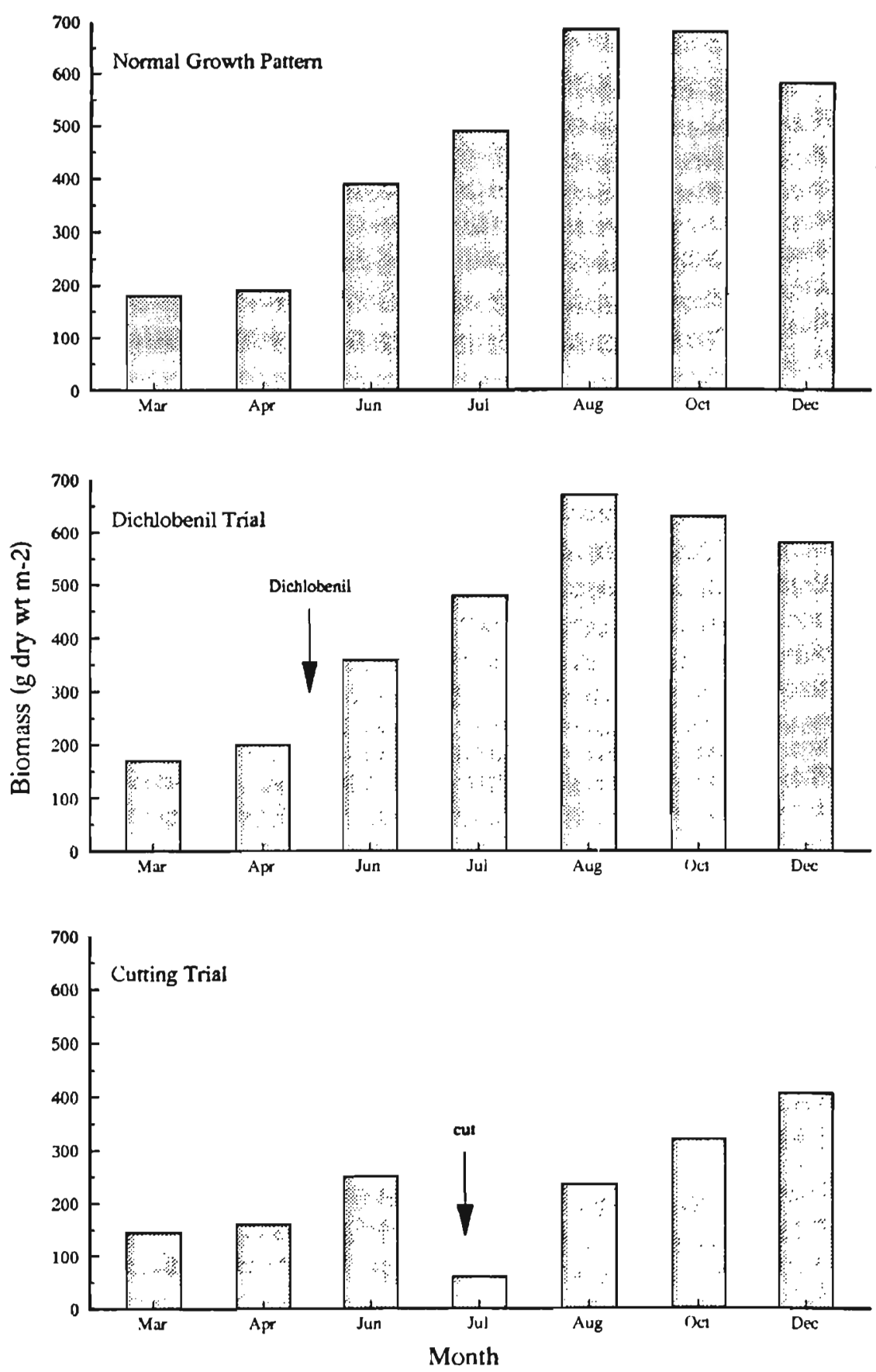

Figure 3. - The normal growth pattern and the effect of dichlobenil treatment and mechanical cutting on the biomass of Potamogeton pectinatus (Fennel pondweed) in the Lower River Shannon in 1991. 
(figure 3). This may reflect the fact that dichlobenil-containing granules were swept downstream with the flow and did not reach the substratum, from which the chemical is absorbed by root uptake. However, care was taken to ensure that flow velocity at a number of the treated sites was minimal $\left(<10 \mathrm{sec}^{-1}\right)$. This result suggests that $P$. pectinatus, under Irish conditions, may be resistant to the activity of dichlobenil. Further work with dichlobenil, and other aquatic herbicides, will continue at infested river sites.

In late-June, 1991, cuts were applied to a number of $P$. pectinatus infested sections on the lower River Shannon. These cutting operations reduced the biomass to circa $50 \mathrm{~g} \mathrm{~m}^{-2}$ and permitted unobstructed angling in the channel. By early-August, however, a significant vegetation had reestablished and again interfered with the beneficial use of the channel (figure 3). Work in the coming seasons will focus on the effects that early season and late season cuts might have one the subsequent growth of $P$. pectinatus and efforts to identify critical phases in the plant's life cycle, when weed control procedures might prove more effective, will continue.

\subsection{Control of Heracleum mantegazzianum (Giant Hogweed) along River Corridors}

Heracleum mantegazzianum is an invasive weed species that is spreading rapidly along river corridors in Ireland.
The successful establishment of the plant in this habitat highlights the importance of water-mediated seed dispersal. The spread is a cause for concern because of the serious human health hazard that the plant represent and because of the ecological and amenity disruption that its widespread establishment can have.

Heracleum mantegazzianum is a perennial plant that takes three or four years to mature. Seedlings first appear in February each year. These produce immature plants that may achieve a height of $0.4 \mathrm{~m}$ in their first year of growth. In September or October this foliage dies back. Early regrowth in February from tap roots is often vigorous in the plants second and third years. If the plant is to mature, flower stalks begin to elongate in May. Peak flowering occurs in lateJune or early-July and seeds are dispersed by the end of September. In the year of flowering the plant can achieve a height of $4 \mathrm{~m}$ (figure 4 ) and up to 100,000 seeds per plant may be produced. Thereafter, the plant dies. If the plant is not to mature in that year, it may achieve a height of up to $1.5 \mathrm{~m}$ before dying back.

In trials where maturing $H$. mantegazzianum plants were cut, to ground level, rapid vegetation regrowth followed (figure 4). In fact, cutting in May induced early flowering and seed production among the cut plants. Where flower and/or seed heads were removed from mature plants, they either established new seeding structures later in the season or postponed seeding until the following year 

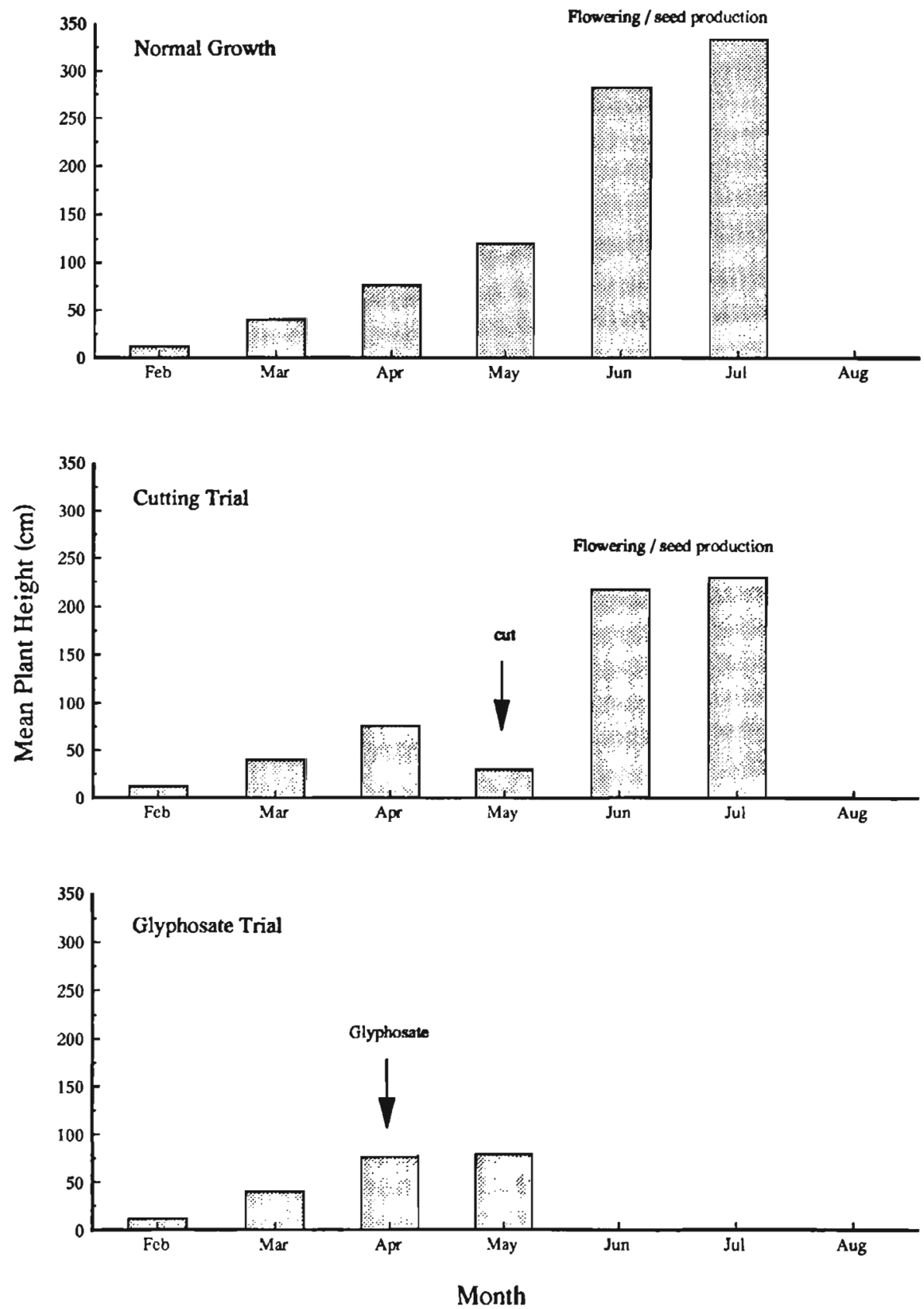

Figure 4. - The normal growth pattern and the effect of cutting and glyphosate treatments on the normal adult growth of Heracleum mantegazzianum (Giant Hogweed) along the River Mulkear in 1992. 
(Caffrey in press). Application of glyphosate at the recommended dose rate $\left(51 \mathrm{ha}^{-1}\right)$, on the other hand, achieved a $100 \%$ plant kill. At these sites no plants matured and no seeds were produced (figure 4). Because the seeds of this plant are capable of lying dormant in the soil for up to 15 years, and because they can be recruited from untreated sections of river bank located upstream, maintenance programmes must be implemented and conducted over a number of years if the plant is to be effectively controlled. If the plant is to be eliminated from a river, sites of infestation throughout the channel must be targeted and included in any maintenance schedule.

\subsection{Algal Control using Barley Straw}

Excessive growths of filamentous algae in lakes, rivers and canals regularly present problems for waterbased leisure activity, as well as for industrial and municipal users. In recent years a considerable research effort has been focused on the ability of decomposing barley straw to inhibit algal growth (Welsh et al., 1990; Gibson et al., 1990). While much remains to be learned regarding the mode of action of straw on algae, research has shown that the primary effect is due to a factor generated during the decomposition of the straw which inhibits the growth of algae (Gibson et al., 1990). The identity of the factor remains unknown. Work in Ireland on this subject was concentrated on canal sections where dense carpets of filamentous green algae, primarily Cladophora glomerata, impeded navigation, obstructed angling, interfered with the functioning of lock gates and detracted from the aesthetics of this unique habitat.

In October, 1990, loose bales of barley straw were submerged along the margins an algal-infested section of canal. Bales were spaced at approximately $50 \mathrm{~m}$ intervals along the trial site. The biomass of filamentous algae at this and at adjacent untreated sites was determined at this time (figure 5). Replacement bales were added to the trial section at roughly 6-month intervals through 1991 and 1992 and biomass determinations were made regularly during this period.

The results, presented in figure 5 , show that the biomass of algae in the untreated site broadly follow a cyclical pattern, with peak crops produced between July and September and low biomass values recorded in February and March. By contrast, in the section containing the straw, the biomass of algae decreased from March to July 1991 and, thereafter, no algae were recorded (figure 5). This has greatly enhanced the amenity potential of this channel and suggests that this weed control procedure should have much wider application in algal-infested watercourses throughout the country.

\section{CONCLUSIONS}

In recent years aquatic weeds have presented some of the most serious 


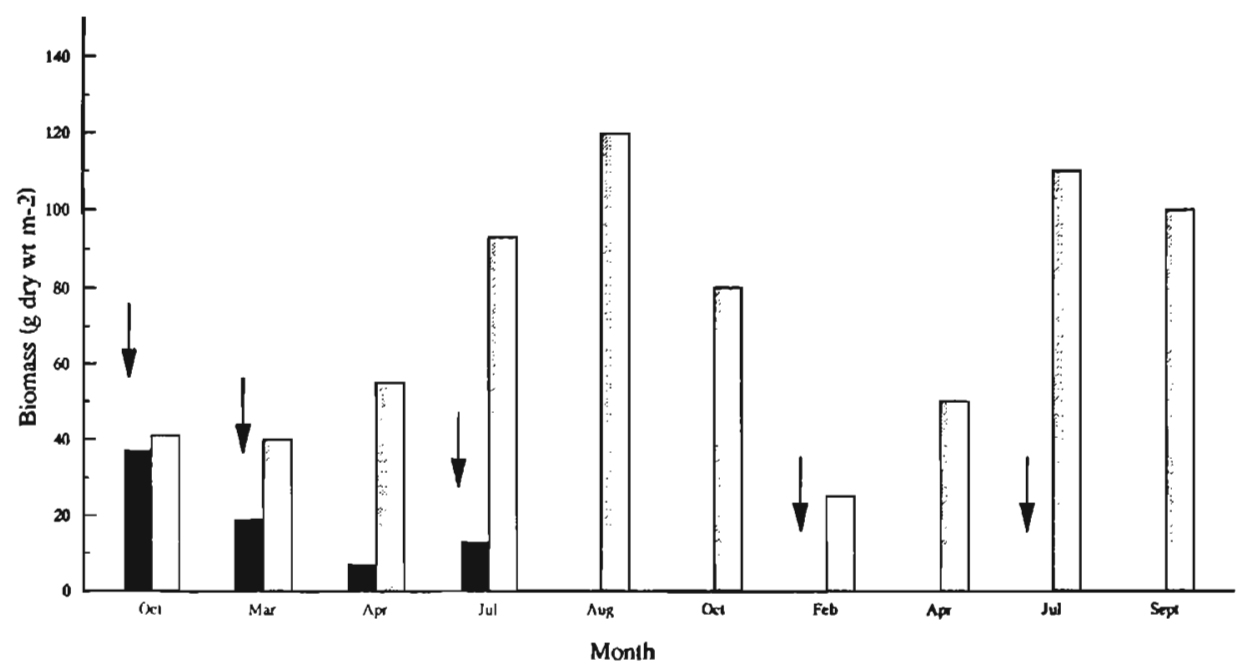

Figure 5. - Biomass of filamentous green algae in sections of the Royal Canal that were treated (dark) and untreated (grey) with barley straw between 1990 and 1992.

$\rightarrow$ Straw introduction/replacement.

problems in the area of water management in Ireland. As the conditions that favour the proliferation of these weed species are unlikely to ameliorate in the short-term it is, therefore, important that environmentally safe and effective strategies for controlling the spread of this vegetation are urgently developed. These control strategies must, however, be sufficiently sensitive to control the target vegetation without adversely impacting non-target flora and fauna and without interfering with the beneficial use of the watercourse.

Extensive research on the environmental impact that herbicides have on aquatic ecosystems has narrowed the range of active ingredients re- commended for use in or near lrish watercourses to four. These are dichlobenil, diquat, terbutryn and glyphosate. These herbicides effectively control their respective target species and, when used with discrimination, have little impact on non-target organisms. While a great deal of time and money has been spent researching the efficacy and environmental impacts that these herbicides have on the aquatic habitat (Pieters and de Boer 1971; Brookers and Edwards 1982; Wade 1982; Caffrey 1988), less work has been conducted on the development of fast, precise and economical herbicide application devices. This probably reflects the relatively limited market for aquatic herbicides by 
comparison with that available for agricultural products. The absence of suitable equipment for applying glyphosate to reeds in relatively inacessible, wide rivers is one case in point and is an area which merits urgent attention.

Advances in mechanical weed cutting and harvesting apparatus in recent years have greatly improved the efficiently of control operations. However, results presented in this paper demonstrate that, unless there is a commitment among water managers to apply deep cuts, it may be necessary to apply two or three cuts during each growing season. The fear among operators of breaking blades on debris lying on the river, canal or lake beds commonly deters them from cutting the vegetation to a depth where light penetration and plant regrowth will be restricted. Efficient and economical mechanical weed cutting operations can only be conducted, in most circumstances, where the cut is applied close to the substratum and provisions must be made to facilitate this type of operation. This may involve removing rubbish prior to the weed cutting operation or fitting blade guards to the cutting equipment.

The ability to effectively cut obstructive vegetation in rivers where riffles, glides and pools regularly alternate and where gravel shoals, rocks and boulders are distributed along the channel remains a serious problem. Amphibious weed cutting boats are available on the market and, while these can effectively cut vegeta- tion in relatively uniform river channels, are less successful in dealing with robust submerged species in fast-flowing, complex river habitats. These plants (e.g. Potamogeton pectinatus) present serious inchannel obstructions in long sections of Irish rivers and, if these channels are to be exploited to their full extent, more effective forms of control must be developed. Engineering work in this area is ongoing.

One of the most significant advances in the area of aquatic weed management in recent years has ben the discovery of the ability of rotted barley straw to effectively control the growth of algae, both phytoplankton and filamentous forms, in aquatic habitats. This means that one of the most troublesome groups of aquatic plants can be managed without the involvement of costly chemicals or mechanical cutting and harvesting machinery. The fact that the straw provides a habitat for fish-food macroinvertebrates represents and additional benefit to the use of this technique. Future research should focus on investigating the availability of further weed control methods that are environmentally safe and may reduce our dependence on more costly and less environmentally-sensitive procedures.

\section{REFERENCES}

Barrett P.R.F., Murphy K.J. and Wade P.M., 1990. The management of aquatic weeds. In, Hance R.J. and Holly K, (Eds), Weed Control Handbook: Prin- 
ciples. Blackwell Scientific Publications, Oxford 473-490 p.

Bronstad J.V. and Friestad H.O., 1985. Behaviour of glyphosate in the aquatic environment. In Grossbard E. and Atkinson D. (Eds.), The Herbicide Glyphosate. Butterworth, London.

Brooker M.P. and Edwards R.W., 1975. Aquatic herbicides and the control of aquatic weeds. Wat. Res.9, 1-15.

Caffrey J.M., 1985. A scheme for the assessment of water quality using aquatic macrophytes as indicators. J. Life Sci., R.D.S., 5: 105-11.

Caffrey J.M., 1986a. Macrophytes as biological indicators of organic pollution in Irish rivers. Proc. RIA Symp. on Biological Indicator of Pollution: 77-87.

Caffrey J.M., 1986b. The impact of peat siltation on the marginal macrophyte comunities in the River Suck: an Irish coarse fishery. Proc. EWRS/AAB 7th Symp. on Aquatic Weeds: 53-60.

Caffrey J.M., 1988. Trials to Evaluate the Environmental Impact of Chemical Weed Control, using Casoron and Midstream, in Selected Irish Waters. Office of Public Works commissioned report, Central Fisheries Board, Dublin.

Caffrey J.M., 1990a. Problems relating to the management of Potamogeton pectinatus L. in Irish rivers. Proc. EWRS 8th. Symp. on Aquatic Weeds, Loughborough: 61-68.

Caffrey J.M., 1990b. The Classification, Ecology and Dynamics of Aquatic Plant Communities in Some Irish Rivers. Ph.D. Thesis, University College Dublin $254 p$

Caffrey J.M., 1991a. Aquatic plant management in Irish rivers. In Steer M.W. (Ed.), Irish Rivers: Biology and Management, Royal Irish Academy, Dublin 85-98 $p$

Caffrey J.M., 1991b. Aquatic plants and plant management in the Inchicore area of the Grand Canal. In Connaghan M., Gleeson O., Maddock A.,
(Eds.) The Grand Canal Inchicore and Kilmainham. Inchicore and Kilmainham Development Project/Office of Public Works 66-68.

Caffrey J.M., 1993. Aquatic plant management in relation to Irish recreational fisheries development. J. Aquat. Plant Manage. 31: 162-168.

Caffrey J.M., 1993. Aquatic weed wanagement practices using dichlobenil: an Irish experience. Pol. Arch. Hydrobiol.: 00-00.

Caffrey J.M. In press. The spread and management of Giant Hogweed (Heracleum mantegazzianum Sommier and Levier) along Irish river corridors. In, Wade M. (Ed.) Ecology and Management of Invasive Riverside Plants. John Wiley and Sons, Ltd. 00-00.

Caffrey J.M. In press. Management of aquatic and invasive riparian vegetation in Irish amenity watercourses. Proc. Conf. on Water of Life, R.D.S., Dublin: 00-00.

Caffrey J.M. and Monahan C., 1991. Aquatic Plant Management in Irish Canals. Annual Report 1990-1991. Office of Public Works commisioned report, Central Fisheries Board, Dublin $56 \mathrm{p}$.

Champ W.S.T. In press. - Lough Sheelin - a success story. Proc. Conf. on Water of Life, R.D.S., Dublin: 00-00.

Dawson F.H. and Kern-Hansen U., 1979. The effect of natural and artificial shade on the macrophytes of lowland streams and the use of shade as a management technique. Intern. Rev. der ges. Hydrobiol. 64: 437-455.

De Nie, H.W. 1987. The decrease in aquatic vegetation in Europe and its consequences for fish populations. EIFAC/ CECPI Occassional paper No. 19: $52 \mathrm{p}$

De Steno F.M., 1992. Controlling water milfoil infestations using an integrated approach. Aquatics 14(2): 4-8.

Gibson M.T., Welch I.M., Barrett P.R.F. and Ridge I., 1990. Barley straw as an 
inhibitor of algal growth II: laboratory studies. J. Appl. Phycol. 2: 241-248.

Goldborough L.G. and Beck A.E., 1989. Rapid dissipation of glyphosate in small forest ponds. Arch. Environ. Contam. Toxicol. 18: 537-544.

Hannon D., 1992. Vegemats - home of big bass. The In-Fisherman 108, 4246.

Haslam S.M., 1978. River Plants. Cambridge University Press, Cambridge. $396 \mathrm{p}$.

Jorga W., Heym W.D. and Weise G., 1982. Shading as a measure to prevent mass development of submerged macrophytes. Int. revue ges. Hydrobiol. 67, 271-281.

Kern-Hansen U. and Holm T.F., 1982. Aquatic plant management in Danish streams. Proc EWRS 6th Symp. on Aquatic Weeds, 122-131.

Madsen J.D. and Adams M.S., 1989. The distribution of submerged aquatic macrophyte biomass in a eutrophic stream, Badfish Creek: the effect of environment. Hydrobiol. 171: 111-119.

Marshall E.J.P. and Westlake D.F., 1978. Recent studies on the role of aquatic macrophytes in their ecosystem. Proc. EWRS 5th Symp. on Aquatic Weeds: 43-51.

Murphy K.J., Fox A.M. and Hanbury R.G., 1987. A multivariate assessment of plant management impacts on macrophyte communities in a Scottish canal. J. Appl. Ecol. 24: 1063-1079.

National Rivers Authority, 1990. Toxic Blue-green Algae. National Rivers Authority, London $128 \mathrm{p}$.

Navas M.L., 1991. Using plant population biology in weed research: a strategy to improve weed management. Weed Res. 31: 171-179.

Newbold C. and Palmer M., 1979. Trophic Adaptions of Aquatic Plants. CST Note No. 18. Internal Report, NCC, London $12 \mathrm{p}$.

Owens M. and Edwards R.W., 1961. The effects of plants on river conditions. II.
Further crop studies and estimates of net productivity of macrophytes in a chalk stream. J. Ecol. 49: 119-126.

Phillips G.L., Eminson D. and Moss B., 1978. A mechanism to account for macrophyte decline in progressively eutrophicated freshwaters. Aq. Bot. 4: 103-126.

Pieters A.J. and de Boer F.G., 1971. Dichlobenil in the aquatic environment. Proc. EWRS 3rd Internat. Symp. on Aquatic Weeds, 183-193.

Schmidt J.C., 1990. How to Identify and Control Water Weeds and Algae. Applied Biochemists, Inc., Wisconsin $108 \mathrm{p}$.

Seagrave C., 1988. Aquatic Weed Control. Fishing News Books, Surrey, England $154 \mathrm{p}$.

Simpson P.S. and Eaton J.W., 1986. Comparative studies of the photosynthesis of the submerged macrophyte Elodea canadensis and the filamentous algae Cladophora glomerata and Spirogyra sp. Aq. Bot. 24: 1-12.

Tiley G.E.D. and Philp B. In press. Giant hogweed and its control in Scotland. In Wade M. (Ed.), Ecology and Management of Invasive Riverside Plants. John Wiley and Sons Ltd. 00-00.

Wade P.M., 1982. The long term effects of herbicide treatment on aquatic weed communities. Proc. EWRS 6th. Symp. on Aquatic Weeds, 278-286.

Welch I.M., Barrett P.R.F., Gibson M.T. and Ridge I., 1990. Barley straw as an inhibitor of algal growth I: Studies in the Chesterfield Canal. J. Appl. Phycol. 2: 231-239.

Westlake D.F., 1975. Macrophytes. In Whitton B.A. (Ed.), Studies in Ecology, Vo. 2: River Ecology. Blackwell Scientific Publications, Oxford, 106-128.

Westlake D.F., 1981. The development and structure of aquatic weed populations. Proc. Aq. Weeds and their Control, 33-47. 
Williams V., 1992. Lake design for recreational use consideration. Land and Water 36: 44-45.

Willis A.J., 1990. Ecological consequences of modern weed control sys- tems. In Hance R.J. and Holly K. (Eds.), Weed Control Handbook: Principles. Blackwell Scientific Publications, Oxford 501-520 p.

Adapté d'une communication présentée au colloque international de Besançon (16-19 novembre 1992) "Les acquis de la limnologie et la gestion des systèmes aquatiques continentaux". 